AGROTROP, 9 (1): 69 - 81 (2019)

e-ISSN: 2654-4008

p-ISSN: 2088-155X

https://doi.org/10.24843/AJoAS.2019.v09.i01.p07

\title{
Aplikasi Remote Sensing dan Geographic Information System untuk Pemetaan Komoditas Unggulan di Kabupaten Badung
}

\author{
IRNAWATI, I KETUT SARDIANA, DAN INDAYATI LANYA*)
}

Program Magister Program Studi Pertanian Lahan Kering, Fakultas Pertanian, Universitas Udayana Jl. PB. Sudirman, Denpasar 80231 Bali

${ }^{*}$ E-mail: indahnet@yahoo.co.id

\begin{abstract}
Applications Remote Sensing and Geographic Information System for Mapping of Superior Commodities in Badung District. Superior commodity is one of the conditions in the development of agricultural areas included in (Regulation of the Minister of Agriculture No. 56 of 2016). As for the development of food crops agriculture is based on land suitability classes found in technical guidelines (Ministry of Agriculture, 2017). The two regulations require that each Province develop a master plan for developing agricultural commodities, which is based on superior commodities and land suitability classes. Quantitative and qualitative methods include: (1) identification and interpretation of land use using satellite imagery, (2) field surveys, (3) re-interpretation of satellite images, (4) Location Quotient (LQ) analysis for competitive superior commodities and Shift Share Analysis (SSA) for comparative advantage, (5) Mapping of superior commodities and land suitability of food crops. The use of paddy fields in Badung Regency is 9069.11 ha, moor (898,797 ha), and mixed gardens $(3898,615$ ha). Competitive superior commodities (LQ) for: (1) paddy rice, located in Abiansemal, Mengwi, North Kuta and Kuta Districts, (2) corn, peanuts, sweet potatoes and cassava in Petang District, (3) soybeans and green beans in Mengwi District. Comparative superior commodities (SSA) of paddy rice are found in the Districts of Petang and Mengwi. While sweet potatoes in Abiansemal District and cassava in Petang District. Potential agroecosystem suitability classes for food crops and secondary crops in the study area are generally classified as very suitable (S1) except in the Petang District which is quite suitable (S2-t, rc1) with a low temperature limiting factor and a rough texture. Increasing the suitability class of paddy and palawija requires fertilizing and adding organic materials to increase production.
\end{abstract}

Keywords: remote sensing, geographic information system, land use, superior commodities, land suitability class

PENDAHULUAN

Komoditas unggulan menjadi suatu sarana

pembangunan

pertanian

yang

memerlukan data dasar potensi sumberdaya

lahan pertanian yang sesuai dikembangkan pada spesifik lokasi. Pengembangan 
IRNAWATI. et al. Aplikasi Remote Sensing dan Geographic Information System untuk...

komoditas pertanian secara berkelanjutan diharapkan dapat memenuhi kebutuhan pangan secara lokal, regional dan nasional. Era globalisasi seperti saat ini sangat diperlukan informasi yang akurat, mudah dan cepat untuk diakses masyarakat luas. Peta komoditas unggulan merupakan salah satu persyaratan dalam master plan pengembangan komoditas pertanian di suatu daerah (Peraturan Mentri Pertanian No 56 Tahun 2016). Hal ini dapat mengatasi terjadinya persaingan jenis komoditas antar wilayah untuk dapat mencapai ketepatan pengembangan komoditas pertanian, baik pilihan wilayah maupun jenis tanamannya. Pengembangan pertanian tanaman pangan didasarkan pada kelas kesesuaian lahan tercantum dalam buku petunjuk teknis (Kementerian Pertanian, 2017). Pemetaan komoditas unggulan telah banyak dilakukan salah satunya oleh Keratorop et al. (2016) mengenai arahan pengembangan komoditas unggulan pertanian tanaman pangan di Kabupaten Boven Digoel Provinsi Papua.

Menurut Lanya et al. (2017) pengembangan wilayah Kabupaten Badung didasarkan pada potensi dan kendala aspek fisik lingkungannya. Berdasarkan karakteristik atau kualitas lahan Kabupaten Badung, memiliki variasi kesesuaian lahan yang sangat beragam, untuk tanaman pangan, hortikultura, maupun untuk perkebunan. Tanaman tersebut dapat menjadi komoditas unggulan disuatu wilayah tertentu. Komoditas unggulan didasarkan pada perbandingan antara produksi di suatu wilayah dengan wilayah lainnya secara administrasi. Oleh karena itu, sering tidak diketahui lokasi penggunaan lahan dari komoditas yang menjadi unggulan. Untuk itu, diperlukan peta penggunaan lahan dari wilayah yang diteliti. Identifikasi penggunaan lahan disuatu wilayah dapat dilakukan secara cepat dengan tingkat ketelitian tinggi melalui teknologi remote sensing. Sedangkan untuk pemetaan penggunaan lahan dilakukan dengan mengggunakan teknologi Geographic Information Systems (GIS). Menurut Lillesand dan Kiefer (1994) remote sensing adalah seni dan ilmu untuk mendapatkan informasi tentang obyek, area atau fenomena melalui analisa terhadap data yang diperoleh dengan menggunakan alat tanpa kontak langsung dengan obyek, daerah ataupun fenomena yang dikaji. Teknik ini menghasilkan beberapa bentuk citra yang selanjutnya diproses dan di interpretasikan guna menghasilkan data yang bermanfaat untuk aplikasi-aplikasi di bidang pertanian kehutanan, geografi, geologi, perencanaan dan bidang-bidang lainnya. Sementara 
Menurut (Jaya, 2002 dalam Aziz et al., 2018)

GIS adalah sistem berbasis komputer yang terdiri atas perangkat keras komputer (hardware), perangkat lunak (software), data geografis dan sumberdaya manusia (brainware) yang mampu merekam, menyimpan, memperbaharui, menganalisis, dan menampilkan informasi yang berefrensi geografis. Kombinasi kedua ilmu tersebut sangat membantu dan mempercepat dalam proses identifikasi, deskripsi obyek dan kumpulan obyek yang dipetakan secara geospasial.

Hasil penelitian penggunaan aplikasi remote sensing dan GIS untuk lahan subak di Gianyar menghasilkan tingkat ketelitian mencapai $98 \%$ (Lanya dan Netera, 2016). Penggunaan aplikasi remote sensing dan GIS lainnya telah diteliti oleh Feronika (2018) mengenai pemetaan lahan sawah subak berbasis remote sensing dan GIS di Kecamatan Mengwi. Berdasarkan uraian tersebut di atas, maka perlu dilakukan penelitian aplikasi remote sensing dan GIS untuk pemetaan komoditas unggulan di Kabupaten Badung dengan tujuan memperoleh data komoditas unggulan secara geospasial baik berdasarkan administrasi, penggunaan lahan maupun kesesuaian lahannya.

\section{Rumusan Masalah}

Berdasarkan uraian latar belakang terdapat permasalahan-permasalahan sebagai berikut :

1. Bagaimana pola penyabaran penggunaan lahan pertanian di Kabupaten Badung dari hasil rekaman citra satelit tahun $2017 ?$

2. Komoditi pertanian apa saja yang menjadi komoditi unggulan kompetitif dan komperatif tanaman pangan di masing-masing kecamatan di Kabupaten Badung dan pola penyebarannya berdasarkan penggunaan lahan?

3. Bagaimana pola penyebaran kelas kesesuaian lahan untuk masing-masing komoditas unggulan tanaman pangan?

\section{Tujuan Penelitian}

Berdasarkan rumusan masalah, maka tujuan penelitian ini adalah sebagai berikut :

1. Pemetaan penggunaan lahan pertanian berbasis remote sensing dan GIS.

2. Mengidentifikasi dan memetakan komoditas unggulan kompetitif dan komperatif yang terdapat di masingmasing kecamatan di Kabupaten Badung.

3. Tersedianya peta kelas kesesuaian lahan untuk komoditas unggulan tanaman pangan. 
IRNAWATI. et al. Aplikasi Remote Sensing dan Geographic Information System untuk...

\section{BAHAN DAN METODE}

\section{Tempat dan Waktu Penelitian}

Penelitian dilaksanakan di lapangan dan di laboratorium. Penelitian lapang dilaksanakan di Kabupaten Badung. Kabupaten Badung secara administrasi terdiri atas enam wilayah kecamatan yaitu: Kecamatan Petang, Abiansemal, Mengwi, Kuta Utara, Kuta, dan Kuta Selatan (Kecamatan ini tidak termasuk dalam penelitian karena tidak terdapat sawah). Penelitian laboratorium dilaksanakan di Laboratorium Manajemen Sumber Daya Lahan Fakultas Pertanian Universitas Udayana. Penelitian di lapang dan laboratorium berlangsung selama enam bulan terhitung mulai Maret sampai Agustus 2018.

\section{Alat dan Bahan}

Alat yang digunakan dalam penelitian ini adalah seperangkat hardware komputer yang digunakan untuk menganalisis citra, Software QGIS 2.18.24, Software microsoft excel 2010, kompas sebagai alat bantu menentukan arah di lapangan, kamera, dan alat tulis. Bahan-bahan yang digunakan dalam penelitian ini adalah: Citra Satelit CNES/Astrium Digital Globe (Google earth tahun 2017) Kabupaten Badung tahun 2017 dan data sekunder karakteristik lahan seperti: iklim, retensi hara, hara tersedia, terrain
(Lanya et al., 2017) serta data statistik tanaman pangan Kabupaten Badung (Badan Pusat Statistik Kabupaten Badung, (20092017).

\section{Metode Pelaksanaan Penelitian}

Penelitian ini menggunakan metode kuantitatif dan metode kualitatif. Metode kuantitatif meliputi: pembangunan data spasial interpretasi citra satelit dengan digitasi on screen dan interpretasi citra secara visual; selanjutnya dilakukan survei lapang untuk pengecekan pola penyebaran penggunaan lahan (sawah, tegalan, dan kebun campuran). Data statistik komoditas pertanian tanaman pangan unggulan (padi sawah, jagung, kacang tanah, kacang kedelai, kacang hijau, ubi jalar, dan ubi kayu) di analisis menggunakan rumus Location Quotient LQ untuk mendapatkan komoditas unggulan kompetitif bila LQ > 1 (Adisasmita, 2005). Sedangkan analisis Share Analysis (SSA) digunakan untuk memperoleh komoditas unggulan komperatif. Komoditas unggulan komperatif terdiri tiga kategori yaitu berdasarkan daya saing, pertumbuhan cepat dn dan komoditas meningkat yang bersifat positif (Mohammad dan Ketut, 2013). Kelas kekesuaian lahan dari masing-masing komoditas unggulan di lakukan melalui evaluasi kesesuaian lahan 
menurut Ritung et al. (2012). Pemetaan lahan sawah mendominasi di seluruh penggunaan lahan, komoditas unggulan, dan kecamatan kecuali di Kecamatan Petang kesesuaian lahan menggunakan aplikasi GIS. yang di dominasi oleh kebun campuran. Hal Metode kualitatif dalam penelitian ini ini disebabkan oleh posisi Kecamatan Petang meliputi pengumpulan data dimulai dari studi yang terdapat di daerah hulu mempunyai pustaka mengumpulkan sumber data dari relief/kemiringan lereng lebih curam Badan Pusat Statistik maupun teori-teori dibanding dengan daerah bagian tengah dan yang mendukung penelitian. hilir. Sedangkan di Kecamatan Mengwi dan Abiansemal serta Kuta Utara dan Kuta

\section{HASIL DAN PEMBAHASAN}

\section{Penggunaan lahan}

merupakan sawah irigasi. Rendahnya luas

Hasil interpretasi citra satelit dan sawah di Kecamatan Kuta disebabkan adanya pengamatan lapang serta digitasi on screen diperoleh penggunaan lahan sawah di daerah penelitian seluas $(9069,11$ ha), tegalan (898,797 ha), kebun campuran (3898,615 ha) disajikan dalam Gambar 1. Berdasarkan Gambar 1 menunjukkan bahwa penggunaan alih fungsi lahan sawah ke non pertanian yang diakibatkan oleh Rencana Tata Ruang Wilayah (RTRW) Kabupaten Badung tahun 2013-2033 (Pemerintah Daerah Kabupaten Badung, 2013), dimana seluruh lahan sawah dialokasikan untuk sarana dan prasarana pariwisata. 
IRNAWATI. et al. Aplikasi Remote Sensing dan Geographic Information System untuk...

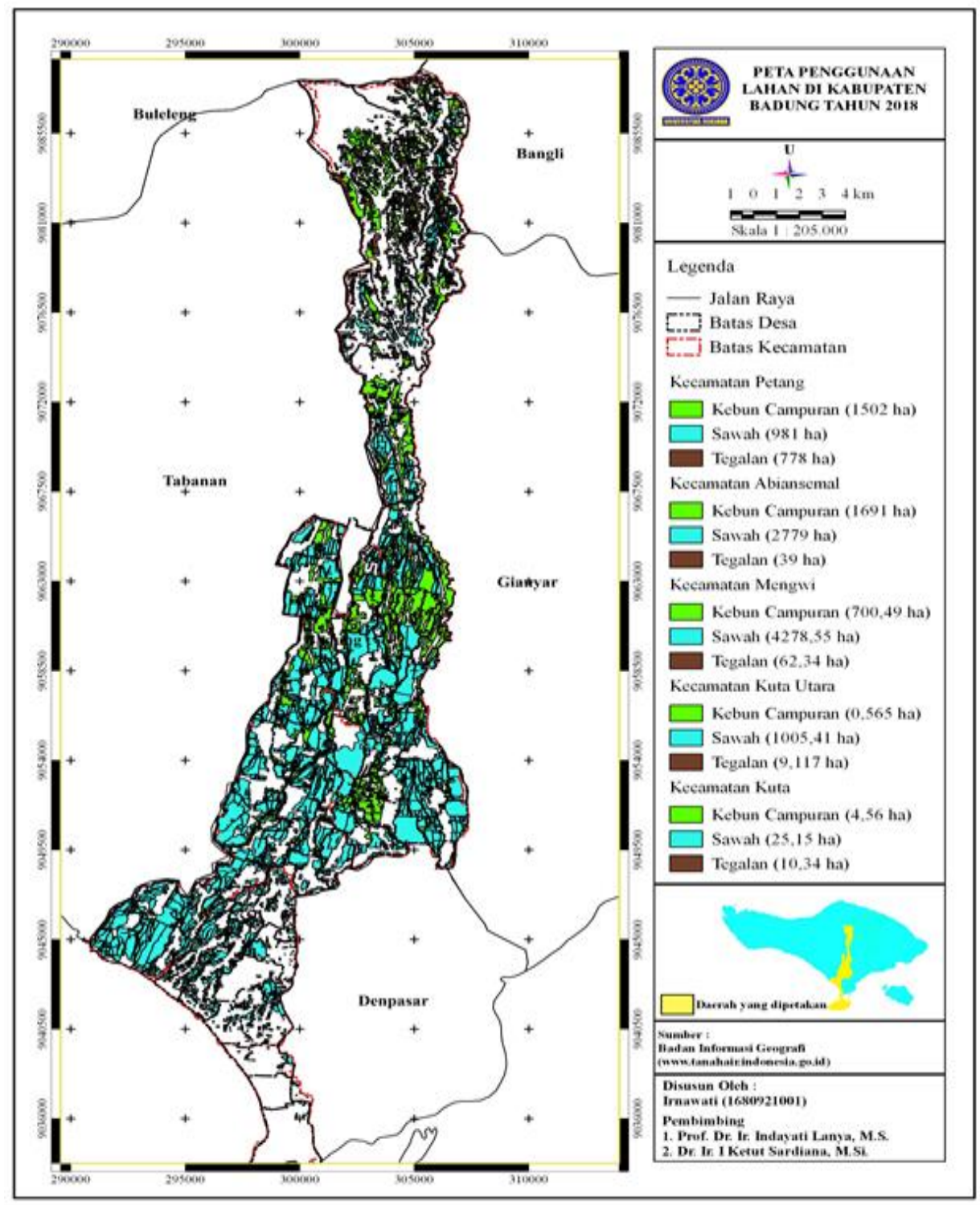

Gambar 1. Peta penggunaan lahan sawah, teglan dan kebun campuran di daerah penelitian tahun 2018

Komoditas Unggulan Kompetitif menunjukkan bahwa seluruh komoditas

\section{Tanaman Pangan}

Data Hasil analisis komoditas unggulan kompetitif dicantumkan dalam Tabel 1; dan ubi kayu merupakan komoditas unggulan Sedangkan peta komoditas unggulan kompetitif. Wilayah penyebaran komoditas kompetitif dicantumkan dalam Gambar 2. padi sawah ada di lima kecamatan di Berdasarkan Tabel 1 dan Gambar 2 Kabupaten Badung kecuali Kecamatan 
Petang. Komoditas jagung, kacang tanah, ubi jalar, dan ubi kayu terdapat hanya di Kecamatan Petang. Kacang kedelai dan kacang hijau merupakan komoditas unggulan yang juga hanya terdapat di Kecamatan Mengwi. Komoditas unggulan kompetitif dengan nilai LQ tertinggi diperoleh pada tanaman ubi jalar $(5,97)$ ubi kayu $(4,27)$, dan kacang tanah $(3,58)$.
Nilai LQ yang tinggi untuk komoditas palawija disebabkan oleh penggunaan lahan tegalan dan kebun campuran yang mendominasi di Kecamatan Petang. Gambar 2 menunjukkan bahwa pola penyebaran komoditas unggulan padi terdapat di seluruh penggunaan lahan sawah, demikian pula kacang kedelai dan kacang hijau. Sedangkan untuk jagung, kacang tanah, ubi jalar dan ubi kayu terdapat di tegalan.

Tabel 1. Nilai LQ komoditas unggulan tanaman pangan di Kabupaten Badung

\begin{tabular}{llllllll}
\hline \multirow{2}{*}{ Kecamatan } & \multicolumn{8}{c}{ Jenis Komoditas } \\
\cline { 2 - 8 } & $\begin{array}{c}\text { Padi } \\
\text { Sawah }\end{array}$ & \multirow{2}{*}{ Jagung } & $\begin{array}{c}\text { Kacang } \\
\text { Tanah }\end{array}$ & $\begin{array}{c}\text { Kacang } \\
\text { Kedelai }\end{array}$ & $\begin{array}{c}\text { Kacang } \\
\text { Hijau }\end{array}$ & $\begin{array}{c}\text { Ubi } \\
\text { Jalar }\end{array}$ & $\begin{array}{c}\text { Kbi } \\
\text { Kayu }\end{array}$ \\
\hline Petang & 0,55 & 3,54 & 3,58 & 0 & 0 & 5,97 & 4,27 \\
Abiansemal & 1,08 & 0,82 & 0,8 & 0,9 & 0 & 0,18 & 0,26 \\
Mengwi & 1,06 & 0,49 & 0,56 & 1,57 & 2,12 & 0,08 & 0,63 \\
Kuta Utara & 1,11 & 0,18 & 0 & 0,53 & 0,49 & 0 & 0 \\
Kuta & 1,09 & 0 & 0 & 0,39 & 0 & 0 & 0 \\
\hline
\end{tabular}

Keterangan:

$L Q<1$ berarti komoditi tersebut tergolong non basis, tidak unggul di Kabupaten Badung. $L Q>1$ berarti komoditi tersebut merupakan komoditi unggulan di Kabupaten Badung. 
IRNAWATI. et al. Aplikasi Remote Sensing dan Geographic Information System untuk...

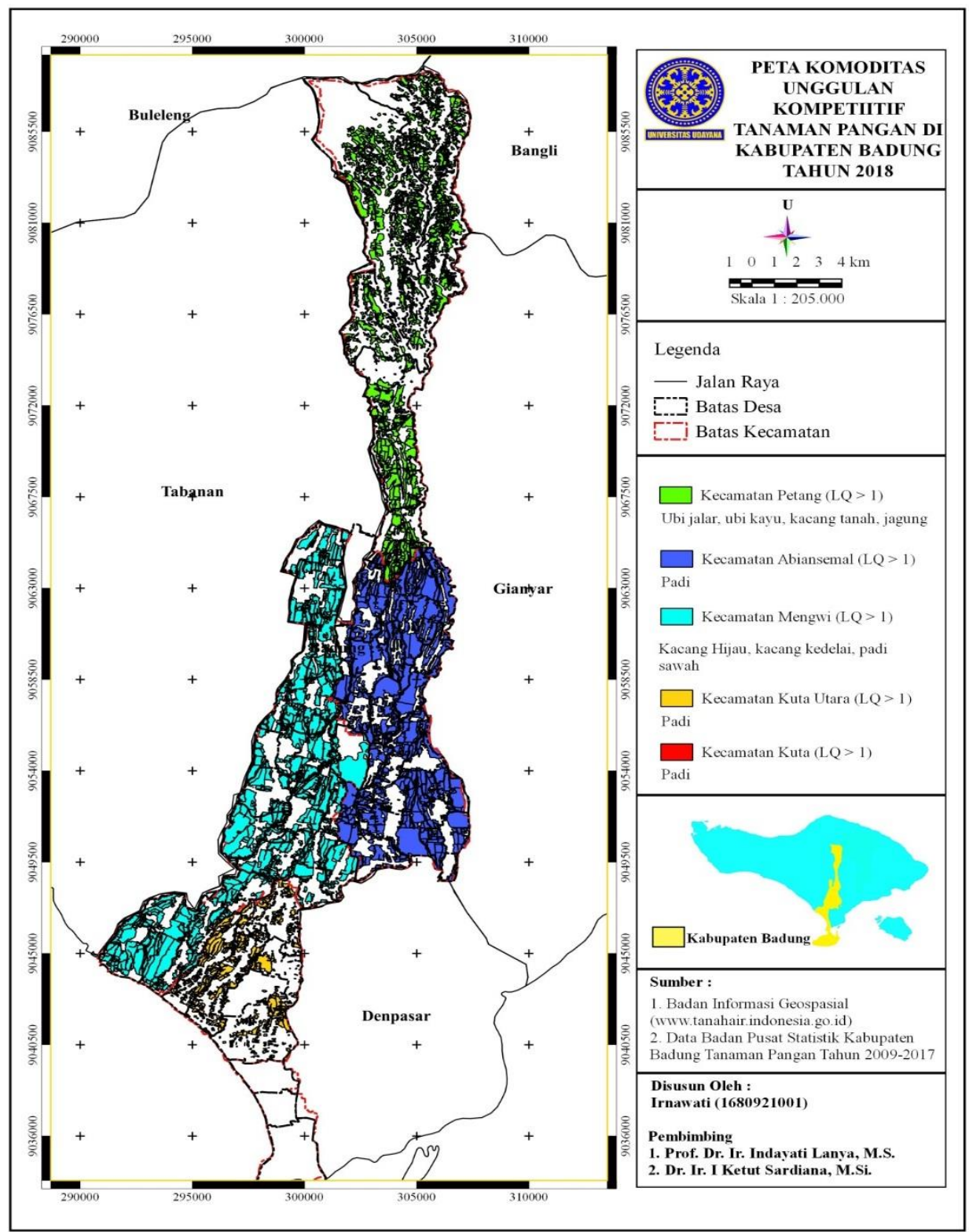

Gambar 2. Peta komoditas unggulan kompetitif tanaman pangan di daerah penelitian

Komoditas Unggulan Komperatif padi sawah terdapat di Kecamatan Petang

\section{Tanaman Pangan}

Hasil analisis SSA diperoleh komoditas unggulan komperatif untuk masing-masing kecamatan disajikan dalam Tabel 2. terdapat di Kecamatan Abiansemal dan ubi Berdasarkan Tabel 2 Komoditas Komperatif kayu di Kecamatan Petang. Berbeda dengan 
Kecamatan Kuta Utara dan Kuta tidak kecamatan lainnya dicantumkan dalam tesis. mempunyai komoditas unggulan komperatif. Kelas kesesuaian agroekosistem secara Peta komoditas unggulan komperatif potensial untuk tanaman pangan dan palawija tanaman pangan di Kabupaten Badung di daerah penelitian secara umum tergolong disajikan dalam Gambar 3. sangat sesuai (S1) kecuali di Kecamatan Petang tergolong cukup sesuai (S2-t,rc1)

Kesesuaian Lahan Komoditas Unggulan

\section{Tanaman Pangan}

Hasil klasifikasi kelas kesesuaian lahan agroekosistem untuk masing-masing komoditas unggulan di masing-masing desa di Kecamatan Abiansemal disajikan pada Gambar 4. Peta kesesuaian lahan untuk lima dengan faktor pembatas suhu yang rendah dan tekstur tanah yang kasar. Peningkatan produksi padi dan palawija diperlukan pemupukan dan penambahan bahan organik untuk meningkatkan daya pegang air dan meningkatkan kelas kesesuaian lahan.

Tabel 2. Nilai SSA komoditas tanaman pangan di Kabupaten Badung

\begin{tabular}{|c|c|c|c|c|c|c|c|c|}
\hline \multirow[b]{2}{*}{ Kecamatan } & \multirow[b]{2}{*}{ Nilai } & \multicolumn{7}{|c|}{ Jenis Komoditas } \\
\hline & & $\begin{array}{c}\text { Padi } \\
\text { Sawah }\end{array}$ & Jagung & $\begin{array}{l}\text { Kacang } \\
\text { Tanah }\end{array}$ & $\begin{array}{l}\text { Kacang } \\
\text { Kedelai }\end{array}$ & $\begin{array}{c}\text { Kacang } \\
\text { Hijau }\end{array}$ & $\begin{array}{l}\text { Ubi } \\
\text { Jalar }\end{array}$ & $\begin{array}{c}\text { Ubi } \\
\text { Kayu }\end{array}$ \\
\hline \multirow{3}{*}{ Petang } & PPW & 519,94 & 0 & 175,21 & - & - & -1195 & 1435,79 \\
\hline & PP & 101,1 & -152 & -14 & - & - & 144,04 & 1054,16 \\
\hline & PB & 621,05 & -152 & 160,86 & - & - & -1051 & 2489,95 \\
\hline Abian- & PPW & $-9145,04$ & 0 & -406 & 0 & - & 44,08 & -675 \\
\hline \multirow[t]{2}{*}{ semal } & PP & 365,39 & -362 & -13 & -324 & - & 1,36 & 167,1 \\
\hline & PB & $-8779,65$ & -362 & -420 & -324 & - & 45,45 & $-508,52$ \\
\hline \multirow[t]{3}{*}{ Mengwi } & PPW & 7607,69 & 0 & 231,42 & 0 & - & - & -760 \\
\hline & PP & 467,53 & -365 & $-3,54$ & -1306 & - & - & 188,25 \\
\hline & PB & 8075,23 & -365 & 227,87 & -1306 & - & - & $-571,9$ \\
\hline Kuta & PPW & -3848 & - & - & 0 & - & - & - \\
\hline \multirow[t]{2}{*}{ utara } & PP & -85059 & - & - & -153 & - & - & - \\
\hline & PB & -85063 & - & - & -153 & - & - & - \\
\hline \multirow[t]{3}{*}{ Kuta } & PPW & $-253,234$ & - & - & 0 & - & - & - \\
\hline & PP & 3,73 & - & - & $-2,799$ & - & - & - \\
\hline & PB & -249 & - & - & $-2,799$ & - & - & - \\
\hline
\end{tabular}

\section{Keterangan :}

PPW $>0$ = Region j memiliki daya saing yang baik pada komoditas i dibandingkan dengan wilayah lainnya $\mathrm{PP}>0 \quad=$ Komoditas $\mathrm{i}$ pada region $\mathrm{j}$ pertumbuhannya cepat

$\mathrm{PB}>0 \quad=$ Pertumbuhan komoditas $\mathrm{i}$ pada wilayah $\mathrm{j}$ termasuk kelompok maju

Nilai PP, PPW, PB negatif (-) artinya komoditas tersebut bukan komoditas unggulan komperatif 
IRNAWATI. et al. Aplikasi Remote Sensing dan Geographic Information System untuk...

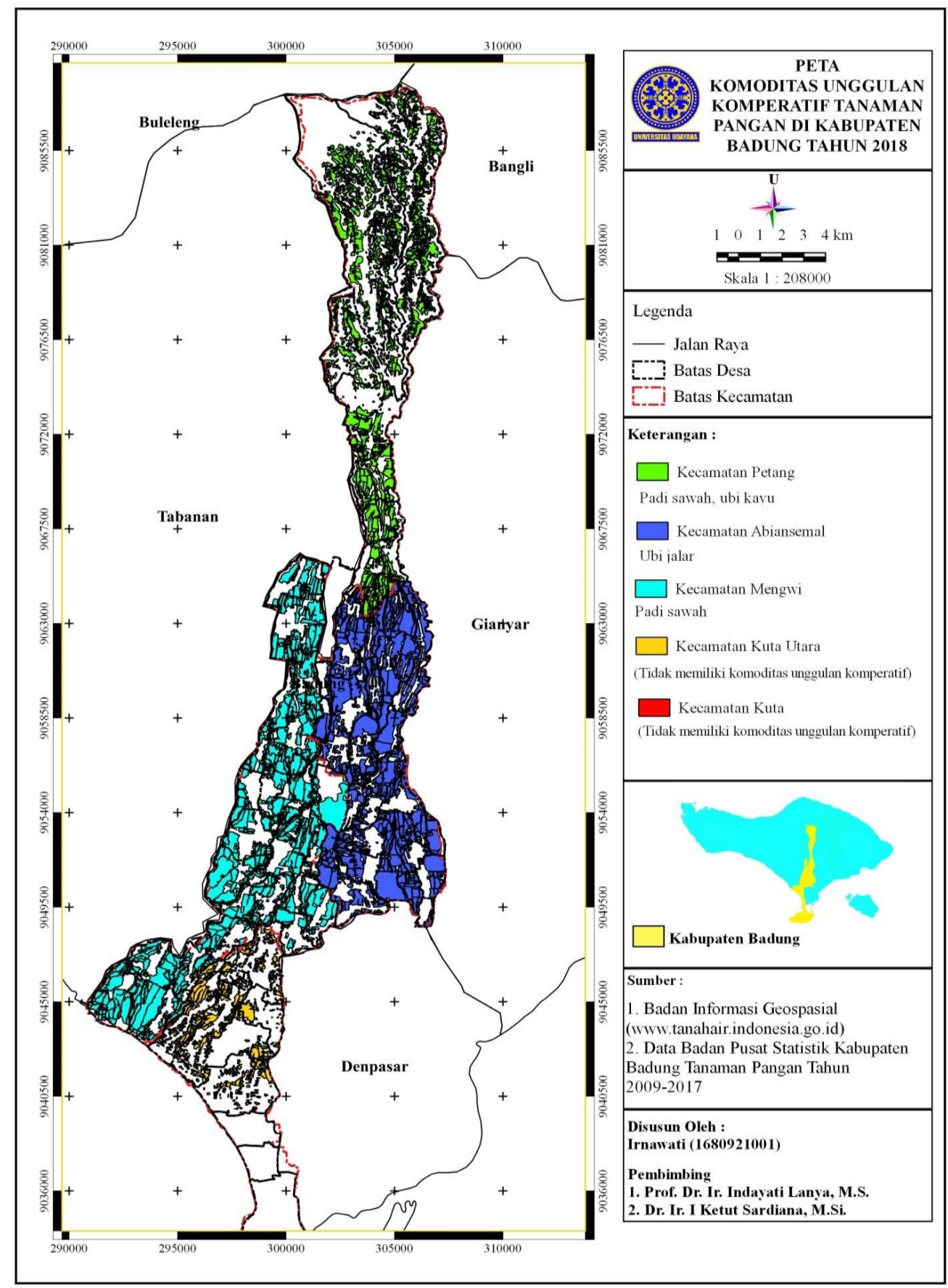

Gambar 3. Peta komoditas unggulan komperatif tanaman pangan di daerah penelitian 


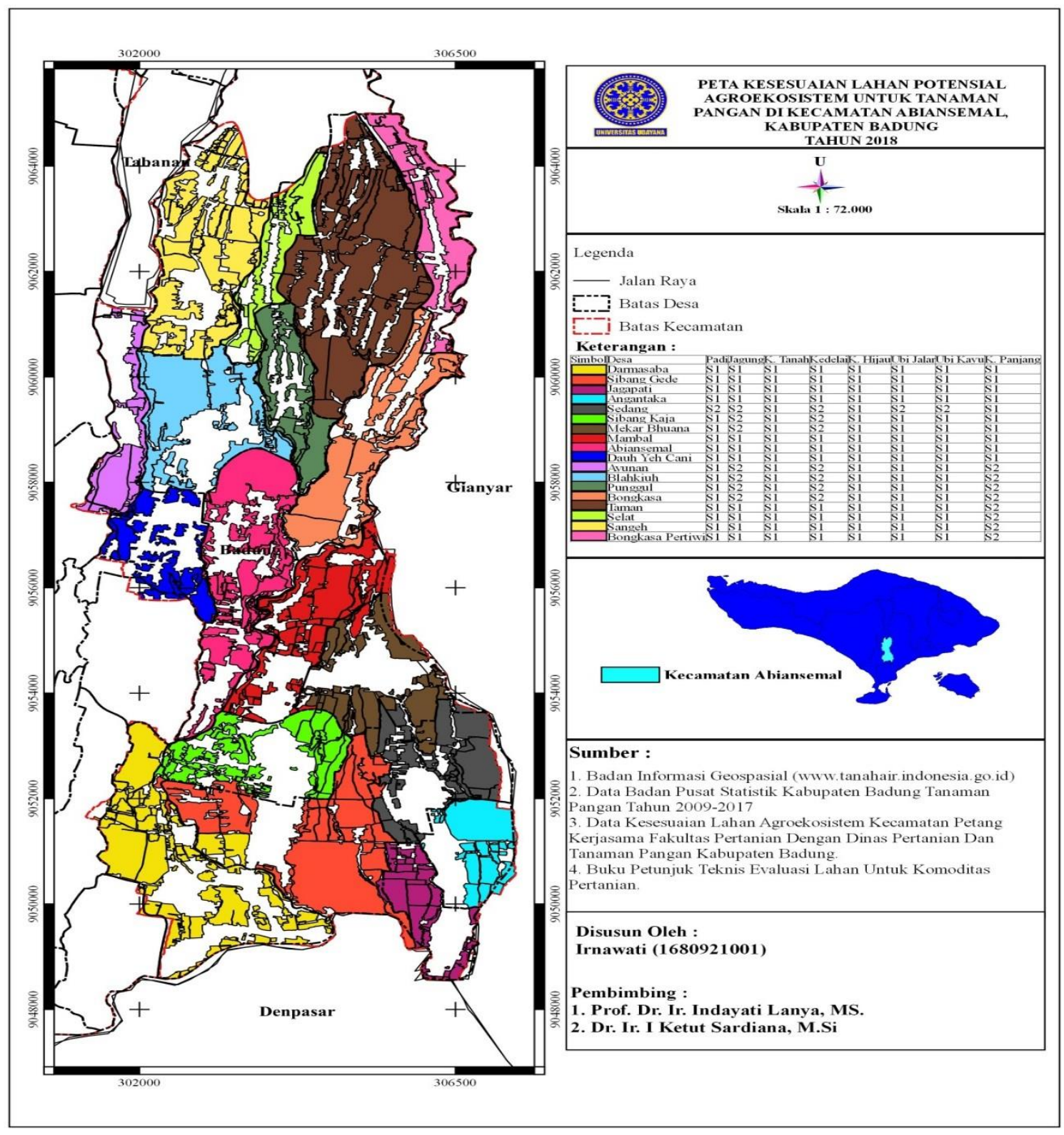

Gambar 4. Peta kelas kesesuaian lahan potensial untuk tanaman pangan di Kecamatan Abiansemal

\section{SIMPULAN}

Penggunaan lahan di Kabupaten Badung tahun 2018 teluas sawah 9.069,11 ha, diikuti kebun campuran 3898,615 ha, tegalan 898,797 ha. Penyebaran lahan sawah terdapat di Kecamatan Mengwi (4278,55 ha), Abiansemal (2779 ha), Kuta Utara (1005,41 ha) dan Kuta (25,15 ha). Kebun campuran tertinggi berada di Kecamatan Abiansemal (1691 ha) berturut-turut diikuti Kecamatan Petang (1502 ha), Kecamatan Mengwi (700,49 ha), Kecamatan Kuta Utara 
IRNAWATI. et al. Aplikasi Remote Sensing dan Geographic Information System untuk...

(0,565 ha), Kecamatan Kuta (4,56 ha).

Tegalan tertinggi Kecamatan Petang (778

ha), Kecamatan Abiansemal (39 ha),

Kecamatan Mengwi (62,34 ha), Kecamatan

Kuta (10,34 ha), kecamatan Kuta Utara

$(9,117$ ha). Padi sawah merupakan

komoditas unggulan kompetitif di empat kecamatan yaitu Abiansemal, Mengwi, Kuta Utara, dan Kuta. Tanaman jagung, kacang tanah, ubi jalar, dan ubi kayu merupakan komoditas unggulan di Kecamatan Petang. Kacang kedelai dan kacang hijau di Kecamatan Mengwi. Komoditas unggulan komperatif untuk padi sawah hanya terdapat di Kecamatan Petang dan Mengwi. Ubi jalar di Kecamatan Abiansemal, dan ubi kayu di Kecamatan Petang. Kelas kesesuaian lahan agroekosistem secara potensial untuk tanaman pangan dan palawija tergolong sangat sesuai (S1) kecuali di Kecamatan Petang tergolong cukup sesuai (S2-tc,rc1) dengan faktor pembatas suhu yang rendah dan tekstur tanah yang kasar.

Penelitian komoditas unggulan dapat digunakan sebagai acuan dalam menyusun master plan dan action plan pengembangan sentral produksi tanaman pangan. Hasil penelitian ini sebagai dasar dalam menyusun perencanaan pembangunan pertanian berkelanjutan di Kabupaten Badung.

\section{DAFTAR PUSTAKA}

Adisasmita, dan Rahardjo. 2005. DasarDasar Ekonomi Wilayah. Yogyakarta : Graha Ilmu. . 68 p

Aziz. G., Y. Ashari, dan N. Fauzi. 2018. Aplikasi Geographic Information Systems (GIS) Menggunakan Software Arcgis Untuk Informasi Hidrologi di Tambang PT Beraucoal Sambarata Mine Operation (SMO) Kecamatan Tanjung Redeb Kabupaten Berau Provinsi Kalimantan Timur. Prosiding Teknik Pertambangan. 4(2): 453-460.

Feronika., Indayati Lanya., dan I Wayan Nuarsa. 2018. Pemetaan Lahan Sawah Subak Berbasis Remote Sensing dan GIS di Kecamatan Mengwi, Kabupaten Badung. JAT. 7(1): 55-63.

Kementerian Pertanian Direktorat Jenderal Tanaman Pangan. 2017. Petunjuk Teknis Pengembangan Kawasan Tanaman Pangan. Hal:1-60.

Keratorop, M., Widiatmaka, Suwardi. 2016. Arahan Pengembangan Komoditas Unggulan Pertanian Tanaman Pangan Di Kabupaten Boven Digoel Provinsi Papua. Jurnal Plano Madani. 5(2):143-157

Lanya, I, and N. Netera Subadiyasa. 2016. Role of Remote Sensing and Geographyc Information System Mapping for Protected Areas Land Rice Field Subak, Buffer Zones, and Area Conversion (Case Studies In Gianyar Regency, Bali Province). IOP Conf. Series: Earth and Environmental Science. 47:1-8.

Lanya, I., Subadiyasa, I.N.N., Trigunasih, N.M., Dibia, I.N., Mega, I.M., Ratna Adi, I.G.P, dan Wikarniti, N.M., 2017. Studi Kesesuaian Lahan Untuk Pengembangan Komoditas Unggulan Di Kabupaten Badung. Laporan Akhir Penelitian, Kerjasama Dinas Pertanian Dan Tanaman Pangan Kabupaten Badung. 
Lillesand and Kiefer. 1994 Remote sensing and Image Interpretation. Third Edition. John Wiley and Sons, New York. 750 pp.

Mentri Pertanian Republik Indonesia. 2016. Peraturan Mentri Pertanian Republik Indonesia No 56/PERMENTAN/RC.040/11/2016 tentang pedoman pengembangan kawasan pertanian. Hal: 1-59.

Mohammad, R. E. S. dan Ketut, D. M. E. H. 2013. Penentuan Kawasan Agroindustri Berdasarkan Komoditas Unggulan di Kabupaten Bondowoso. Jurnal Teknik Pomits . 2(2): 109-113.

Ritung, S., Nugroho K., Mulyani, A, dan Suryani. E. 2012. Petunjuk Teknis Evaluasi Lahan Untuk Komoditas Pertanian. Balai Besar Penelitian dan Pengembangan Sumberdaya Lahan Pertanian. Badan Penelitian dan Pengembangan Pertanian, Kementrian Pertanian. Bogor. $98 \mathrm{p}$ 